\title{
Validation of the Arabic Version of the Inventory of Coping Strategies of Competitive Sport (ISCCS)
}

\author{
Jamel Hajji' ${ }^{1}$ Mohamed Baaziz², Sofiene Mnedla ${ }^{3}$, Zouhier Ben Jannet ${ }^{2}$, Ali Elloumi4 \\ ${ }^{1}$ Faculty of Humanities at TUNIS, The Department of Education Sciences, University of Tunis, Tunis, Tunisia \\ ${ }^{2}$ Higher Institute of Sport and Physical Education Gafsa, Gafsa University, Gafsa, Tunisia \\ ${ }^{3}$ Higher Institute of Sport and Physical Education Ksar Said, Mannouba University, Mannouba, Tunisia \\ ${ }^{4}$ Department of Arts and Social Sciences, Sfax University, Sfax, Tunisia \\ Email:makwiss@yahoo.fr
}

How to cite this paper: Hajji, J., Baaziz, M., Mnedla, S., Jannet, Z. B., \& Elloumi, A. (2016). Validation of the Arabic Version of the Inventory of Coping Strategies of Competitive Sport (ISCCS). Advances in Physical Education, 6, 312-327. http://dx.doi.org/10.4236/ape.2016.64032

Received: August 16, 2016

Accepted: October 11, 2016

Published: October 14, 2016

Copyright (c) 2016 by authors and Scientific Research Publishing Inc. This work is licensed under the Creative Commons Attribution International License (CC BY 4.0).

http://creativecommons.org/licenses/by/4.0/ (c) (i) Open Access

\begin{abstract}
The aim of our study is to validate the Arabic version of the inventory of coping strategies of competitive sports (ISCCS) using factor analysis. After critical analyses of adapted sports versions, Gaudreau and Blondin (2002) proposed the ISCCS questionnaire to measure coping strategies in the field of competitive sports (André \& Laurencelle, 2010). The ISCCS identify ten coping strategies that are divided in two dimensions: the coping task-oriented and the coping emotion-oriented. 419 athletes (273 men and 146 women; age $16.79 \pm 3.82$ years, 14 to 34 ) in different individual and team competitions, volunteered to participate in the study. Data were collected and analyzed for reliability and validity using the test-retest method, reliability, correlation analysis and confirmatory factor analyses. Statistical analysis was performed with SPSS version 22.0.0 the IBM AMOS. The confirmatory factor analyses showed good adjustments for coping models of task-oriented (chi-square 359.35, CFI: 0.92; TLI: 0.91; GFI: 0.93; RMSEA: 0.040 and $p$ value $<0.001$ ), and the coping oriented emotion (chi-square 215.45, CFI: 0.93; TLI: 0.91; GFI, 0.94; RMSEA: 0.054 and $p<0.001$ ). In conclusion, ISCCS was translated and validated in various languages, including French, English, Spanish, and Turkish... Arabic version demonstrated good psychometric properties adjustments and can be used in other surveys in the area of sports competition.
\end{abstract}

\section{Keywords}

Coping Strategies, Coping Task-Oriented, Emotion-Oriented Coping, Validity, Arabic Language

\section{Introduction}

Coping is getting more and more attention in the sport field (Bruchon, 2002; Beal, 
Weiss, Barros \& MacDermid, 2005); it helps to better understand the explanatory mechanisms between stressful events and their consequences (Doron, Stephan, \& Le Scanff, 2013; Hoar, Kowalski, Gaudreau, \& Crocker, 2006).

In terms of performance optimization, the athlete must confront the stressful situation in order to maximize its chances of success (Molinero, Salguero, \& Márquez, 2010).

Lazarus and Folkman (1984) define coping as the set of cognitive and behavioral efforts to master the external and/or the internal voltages that mobilize or exceed human resources. Lazarus and Folkman (1984) propose the transactional model. It offers two dimensions of coping strategies: coping oriented problem (TOC) and coping oriented emotions (WCC) (Ponnelle \& Lancry, 2002; Gaudreau \& Blondin, 2002; Skinner, Edge, Altman, \& Sherwood, 2003). The coping strategy is affected by personal characteristics (Costa, Somerfield, \& Mac Crae, 1996), and the specific stressful circumstances (Chabrol \& Callahan, 2004).

Two methodologies are used to measure the coping (Crocker \& Major, 1998; Folkman \& Moskowitz, 2000; Nicholls \& Polman, 2007). The first is based on lists of thoughts or behaviors to manage stressful situations retrospective. Several questionnaires illustrate this methodology, such as the Ways of coping (Folkman and Lazarus, 1980), the COPE (Carver, Scheier, \& Weintraub, 1989), the Coping inventory's response (Moos, 1993), the Coping strategy indicator (Amirkhan, 1990) or the Coping inventory for stressful situations (Endler \& Parker, 1990).

The second methodology is the Daily coping inventory developed by Stone and Neale (1984). It avoids the response distortion on an extended recall in the first methodology. In the Daily coping inventory, people are asked the same day the stressful situation. Recent studies develop and implement methods that would minimize the retrospective bias (Calmeiro \& Tenenbaum, 2007; Calmeiro, Tenenbaum, \& Eccles, 2010, 2014; Doron \& Gaudreau, 2014; Evans, Hoar, Gebotys, \& Marchesin, 2014; Gaudreau et al., 2010).

Generally all instruments adapted to the sports field: the WCQ (Folkman and Lazarus (1980)) as well as the COPE (Carver et al., 1989) have shown questionable results (Nicholls \& Polman, 2007). The exception is the Athletic Coping Skills Inventory-28 (ACSI-28) developed by Smith, Schutz, Smoll, \& Ptacek (1995), the Coping Style Inventory for Athletes (CSIA), developed by Anshel and Kaissidis (1997), the Coping Style Scale for Sport (CSSS), created by Anshel, Williams and Williams (2000) and the Coping Function Questionnaire for Adolescent and Sport developed by Kowalski and Crocker (2001).

Gaudreau and Blondin (2002) have proposed an inventory of coping strategies in sports competition (coping strategies in sports competition inventory), specifically designed for the sport questionnaire. The ISCCS was created to evaluate athlete's actions to prepare for a competition (pre-competition) and those used for sporting competition (Gaudreau \& Blondin, 2002). The ISCCS included a literature review of the coping actions used by sportsmen and a study analysis of the coping pressure, anxiety, and performance (André \& Laurencelle, 2010). These two steps have allowed Gaudreau and Blondin to identify six subscales belonging to TOC: mental imagery, control of though- 
ts, relaxation, invested effort, research support, and logical analysis. Also, four subscales belonging to the WCC are defined: the extraction of negative emotions, the mental distraction, the resignation and the social avoidance.

Besides its original language (French Canada), the ISCCS is validated in several other versions, such as the English version by the same authors (Gaudreau \& Blondin, 2002), the Turkish version (Arsan \& Koruç, 2011), the Spanish version (Campillo, Salguero, Márquez, \& Molinero, 2013).

The purpose of this study is to explore the validation of the Arabic version of ISCCS and examine its psychometric properties.

\section{Methodology}

The sample used in this study consists of 419 athletes (273 male and 146 female) that have voluntarily participated in this study (mean age 16.79 years and 3.82 ). They represent different competitive disciplines, including 294 team sports and 125 individual sports.

All our athletes regularly participate in official competitions nationwide, among them international required preparing to take part in the Olympic Games in 2016 (the Tunisian national team of canoe Kayak).

\section{Procedure}

Gaudreau and Blondin (2002) proposed the ISCCS. They identify 39 items, divided into ten subscales (mental imagery, control of thoughts, relaxation, invested effort, seeking support, analysis logic, negative emotions extraction, mental distraction, resignation and social avoidance).

We are referred to the back-translation procedure (see Vallerand, 1989) to get the translation of the Arabic ISCCS version.

Athlete participation was voluntary. We require managers and coaches authorization of each athlete. Their anonymity was assured, and parental consent is required for those under 18 years.

Before data collection, all athletes were widely informed about the purpose and study procedures, and were informed that the results would be made available at the end of the study. Participants respond to a Liker scale of 5 points, ranging from 1 (never) to 5 (always). Each participant completed a socio-demographic form indicating their age, gender, sport and its affiliate club. The ISCCS was administered 2 hours at maximum 1 day after competition. According to Gaudreau and Blondin (2002), the peculiarity of this questionnaire is to be used before, during and after competition. Unfortunately, we were forbidden to ask athletes before and during the competition. Therefore, our study is limited to the after competition period.

\section{Data Analysis}

Data descriptive analyses of study groups (mean, standard deviation) are provided in Table 1.

The ISCCS temporal stability 
Table 1. Mean scores and the respective standard deviations for each subscale of the ISCCS.

\begin{tabular}{ccc}
\hline Subscales & Mean & Standard deviation \\
\hline Mental imagery & 15.63 & 3.17 \\
Thought control & 15.76 & 3.42 \\
Effort expenditure & 12.82 & 2.47 \\
Seeking support & 13.78 & 3.72 \\
Relaxation & 14.03 & 3.43 \\
Logical analysis & 14.98 & 3.59 \\
Venting of unpleasant emotions & 13.69 & 4.10 \\
Disengagement & 14.15 & 4.47 \\
Social withdrawal & 11.26 & 3.89 \\
Mental distraction & 9.76 & 4.11 \\
\hline
\end{tabular}

We calculate the test-retest index to study the ISCCS temporal stability. The athlete is observed twice times by waiting a certain period of time between two collections ( 2 weeks). The stability is established by the degree of correlation between the answers provided by the same subject $(\mathrm{N}=20)$, (Shrout \& Fleiss, 1979).

Internal consistency was measured by calculating the Cronbach's alpha coefficient between the subscales of the questionnaire. It assesses whether each of the elements reproduced repeatedly and consistently measuring the same construct.

We observed a large number of participants (419) which is higher than the minimum number of 300 suggested by Tabachnick and Fidell (1996). Confirmatory factor analysis (CFA) was treated with AMOS 22.0.0, in order to validate the structure and arrangement of ISCCS factors.

We use several indices of adequacy (Hoyle \& Panter, 1995; Kline, 2005) to evaluate the fit models to data collected such as the $\chi^{2}$ statistic that overcomes the abnormality data (Sattora and Bentler, 1994), the compared fit index CFI (Bentler, 1990) and TLI (Tucker-Lewis Index), the Goodness of Fit Index GFI (Jöreskog \& Sörbom, 1984) and the Root Mean Square error of approximation RMSEA (Browne \& Cudeck, 1993).

Finally, we conduct a MANOVA analysis to examine the effects of gender and sport (collective and individual sports) on the use of coping strategies.

\section{Results}

\subsection{Descriptive Analyses}

The mean scores and the respective standard deviations for each sub-level are presented in Table 1.

\subsection{The Temporal Stability of the Instrument}

The reliability data test-retest is studied by the correlation coefficients between the 
scores of the ISCCS subscales (see Table 2 and Table 3 ).

As concerned with coping strategies, the Pearson correlation coefficient is 0.95 (Effort Expenditure) and 0.69 (mental distraction), ( $p \leq 0.001)$. Furthermore, overall score correlation coefficient of the questionnaire is $0.97(p<0.001)$.

\subsection{The Internal Consistency, Cronbach Alpha}

Measured using Cronbach's alpha, the internal consistency of the Arabic version of ISCCS demonstrated good reliability (Table 4). The coefficients of different coping strategies are from 0.63 to 0.75 . For the two dimensions (coping task-oriented and

Table 2. The test-retest coefficients for the subscales TOC of the ISCCS.

\begin{tabular}{ccccccc}
\hline & $\begin{array}{c}\text { Mental } \\
\text { imagery }\end{array}$ & $\begin{array}{c}\text { Thought } \\
\text { control }\end{array}$ & $\begin{array}{c}\text { Effort } \\
\text { expenditure }\end{array}$ & $\begin{array}{c}\text { Seeking } \\
\text { support }\end{array}$ & Relaxation & $\begin{array}{c}\text { Logical } \\
\text { analysis }\end{array}$ \\
\hline Pearson correlation & 0.782 & 0.901 & 0.949 & 0.940 & 0.910 & 0.816 \\
Significance level $p$ & 0.000 & 0.000 & 0.000 & 0.000 & 0.000 & 0.000 \\
$\mathrm{~N}$ & 20 & 20 & 20 & 20 & 20 & 20 \\
Number of the elements & 4 & 4 & 3 & 4 & 4 & 4
\end{tabular}

Table 3. The test-retest coefficients for the subscales EOC of the ISCCS.

\begin{tabular}{ccccc}
\hline & Venting of unpleasant emotions Disengagement Social withdrawal Mental distraction \\
\hline Pearson correlation & 0.888 & 0.868 & 0.721 & 0.690 \\
Significance level $p$ & 0.000 & 0.000 & 0.000 & 0.001 \\
$\mathrm{~N}$ & 20 & 20 & 20 & 20 \\
Number of the elements & 4 & 4 & 4 & 4 \\
\hline
\end{tabular}

Table 4. Reliability coefficients for the ten factors in the Arabic version and original version of ICSSC.

\begin{tabular}{ccc}
\hline Subscales & $\begin{array}{c}\text { Cronbach alpha } \\
\text { of the Arabic version }\end{array}$ & $\begin{array}{c}\text { Cronbach alpha } \\
\text { the original version } \\
\text { Gaudreau \& Blondin, 2002 }\end{array}$ \\
\hline Mental imagery & 0.67 & 0.74 \\
Thought control & 0.66 & 0.73 \\
Effort expenditure & 0.63 & 0.79 \\
Seeking support & 0.67 & 0.70 \\
Relaxation & 0.63 & 0.80 \\
Logical analysis & 0.70 & 0.67 \\
Venting of unpleasant emotions & 0.74 & 0.87 \\
Disengagement & 0.75 & 0.68 \\
Social withdrawal & 0.69 & 0.71 \\
Mental distraction & 0.72 & 0.76
\end{tabular}


oriented coping emotion) coefficients are 0.81 and 0.64 respectively. Otherwise, the overall coefficient of the questionnaire is 0.78 .

\subsection{Relations between the Subscales of ISCCS}

Significant positive correlations $(p<0.05)$ were observed respectively between mental imagery, the mind control, relaxation, the deployment effort, seeking social support, logical analysis, breakdown of unpleasant emotions and disengagement (between 0.109 and 0.606$)$. The correlation coefficient between isolation and relaxation is 0.180 and between isolation and mental distraction is 0.189 .

As shown in Table 5, mental distraction, mental imagery, control of thoughts, Effort Expenditure, logical analysis, the breakdown of unpleasant emotions and disengagement are negatively and significantly correlated $(p<0.05)$. The scores range from -0.219 to -0.100 . A negative correlation is observed also between isolation, the breakdown of unpleasant emotions and disengagement between -0.173 and -0.101 .

\subsection{Confirmatory Factor Analysis}

The six factors model statistics are: $\left[\mathrm{X}^{2}=359.35 ; p<0.001 ; \mathrm{df}: 215 ; \mathrm{X}^{2} / \mathrm{df}=1.67\right.$; CFI $=$ $0.92 ; \mathrm{TLI}=0.91 ; \mathrm{GFI}=0.93$ and $\mathrm{RMSEA}=0.040]$.

Table 5. Correlations between the subscales of ISCCS.

\begin{tabular}{|c|c|c|c|c|c|c|c|c|c|c|}
\hline Subscales & & 1 & 2 & 3 & 4 & 5 & 6 & 7 & 8 & 9 \\
\hline Mental imagery & & 1 & & & & & & & & \\
\hline \multirow{2}{*}{ Thought control } & Pearson correlation & $0.306^{\star *}$ & 1 & & & & & & & \\
\hline & Significance level $p$ & 0.000 & & & & & & & & \\
\hline \multirow{2}{*}{ Effort expenditure } & Pearson correlation & $0.337^{\star *}$ & $0.378^{\star *}$ & 1 & & & & & & \\
\hline & Significance level $p$ & 0.000 & 0.000 & & & & & & & \\
\hline \multirow{2}{*}{ Seeking support } & Pearson correlation & $0.187^{\star \star}$ & $0.204^{\star *}$ & $0.148^{\star *}$ & 1 & & & & & \\
\hline & Significance level $p$ & 0.000 & 0.000 & 0.002 & & & & & & \\
\hline \multirow{2}{*}{ Relaxation } & Pearson correlation & $0.255^{\star *}$ & $0.194^{\star *}$ & $0.110^{*}$ & $0.208^{\star *}$ & 1 & & & & \\
\hline & Significance level $p$ & 0.000 & 0.000 & 0.025 & 0.000 & & & & & \\
\hline \multirow{2}{*}{ Logical analysis } & Pearson correlation & $0.403^{\star *}$ & $0.309^{\star *}$ & $0.393^{\star *}$ & $0.241^{\star *}$ & $0.295^{\star *}$ & 1 & & & \\
\hline & Significance level $p$ & 0.000 & 0.000 & 0.000 & 0.000 & 0.000 & & & & \\
\hline \multirow{2}{*}{ Venting of unpleasant emotions } & Pearson correlation & $0.117^{\star}$ & $0.109^{*}$ & $0.159^{\star *}$ & 0.084 & 0.044 & 0.072 & 1 & & \\
\hline & Significance level $p$ & 0.017 & 0.026 & 0.001 & 0.085 & 0.370 & 0.141 & & & \\
\hline \multirow{2}{*}{ Disengagement } & Pearson correlation & $0.232^{\star *}$ & $0.156^{* *}$ & $0.202^{\star *}$ & $0.189^{\star *}$ & $0.146^{* *}$ & $0.178^{* *}$ & $0.606^{* *}$ & 1 & \\
\hline & Significance level $p$ & 0.000 & 0.001 & 0.000 & 0.000 & 0.003 & 0.000 & 0.000 & & \\
\hline \multirow{2}{*}{ Social withdrawal } & Pearson correlation & -0.001 & $-0.101^{\star}$ & 0.014 & 0.043 & $0.180^{\star *}$ & 0.027 & $-0.173^{\star \star}$ & $-0.106^{\star}$ & 1 \\
\hline & Significance level $p$ & 0.977 & 0.039 & 0.774 & 0.380 & 0.000 & 0.583 & 0.000 & 0.030 & \\
\hline \multirow{2}{*}{ Mental distraction } & Pearson correlation & $-0.111^{\star}$ & $-0.122^{*}$ & $-0.100^{*}$ & -0.040 & 0.063 & $-0.219^{* *}$ & $-0.128^{\star *}$ & $-0.156^{\star \star}$ & $0.189^{\star *}$ \\
\hline & Significance level $p$ & 0.023 & 0.013 & 0.041 & 0.417 & 0.201 & 0.000 & 0.009 & 0.001 & 0.000 \\
\hline
\end{tabular}


The four factors model statistics are: $\left[\mathrm{X}^{2}=215.45 ; p<0.001 ; \mathrm{df}: 98 ; \mathrm{X}^{2} / \mathrm{df}=2,20\right.$; CFI $=$ 0.93; TLI $=0.91$; GI $=0.94$, and RMSEA $=0.054$ ], see Table 6 .

The two hypothetical models (6 factors (TOC) and 4 factors (EOC)) parameters were statistically significant at $p<0.05$ (see Figure 1 and Figure 2).

Table 6. Confirmatory factor analysis and models of the ISCCS.

\begin{tabular}{cccccccc}
\hline Models & $\mathrm{X}^{2}$ & $\mathrm{df}$ & $\mathrm{X}^{2} / \mathrm{df}$ & $\mathrm{CFI}$ & $\mathrm{TLI}$ & GFI & RMSEA \\
\hline 6 FACTOR COT & 359.35 & 215 & 1.67 & 0.92 & 0.91 & 0.93 & 0.040 \\
4 FACTOR EOC & 215.45 & 98 & 2.20 & 0.93 & 0.91 & 0.94 & 0.054 \\
\hline
\end{tabular}

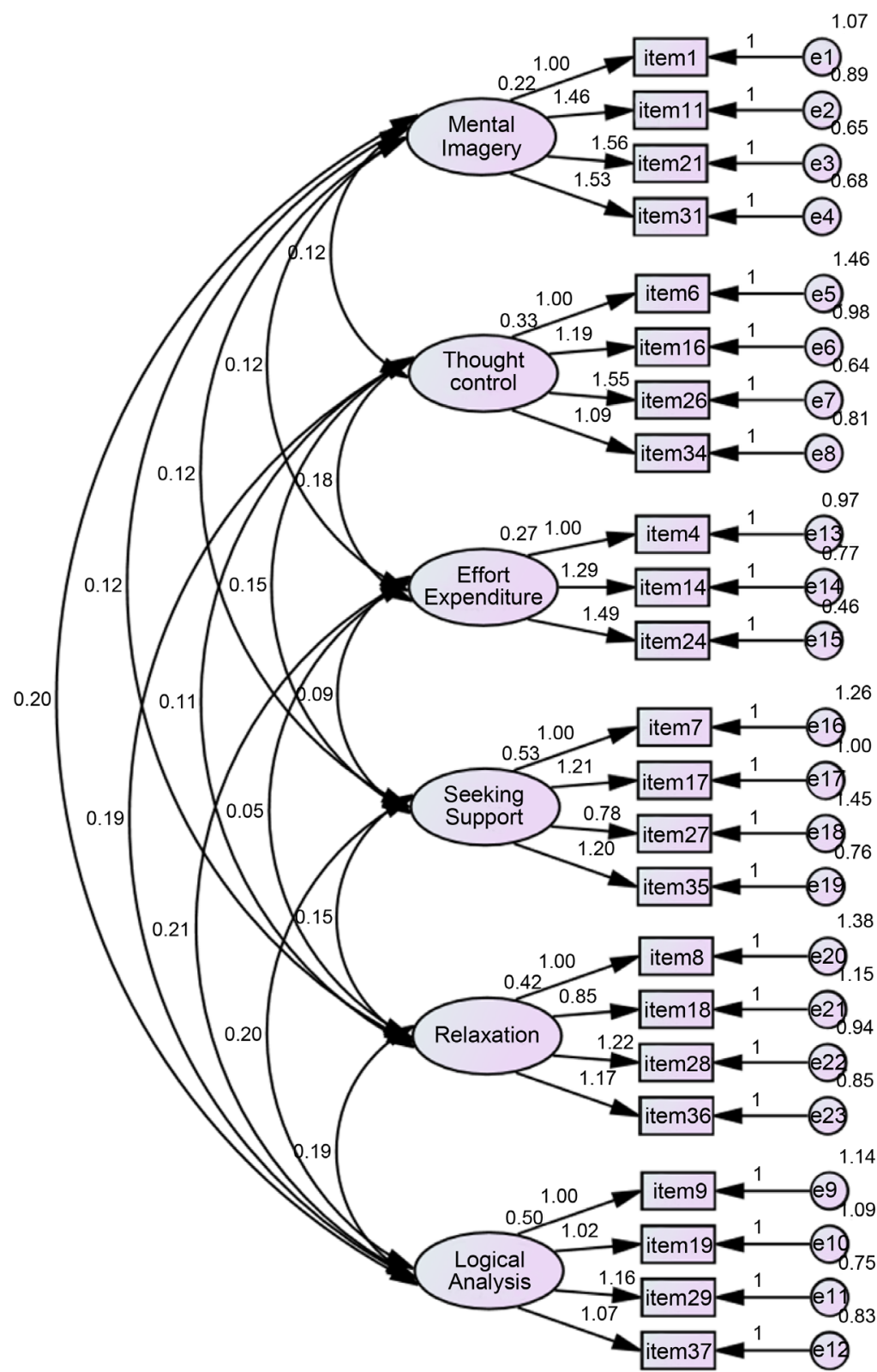

Figure 1. The hypothesized model of 6-factor (TOC) of the Arabic version of ISCCS. 


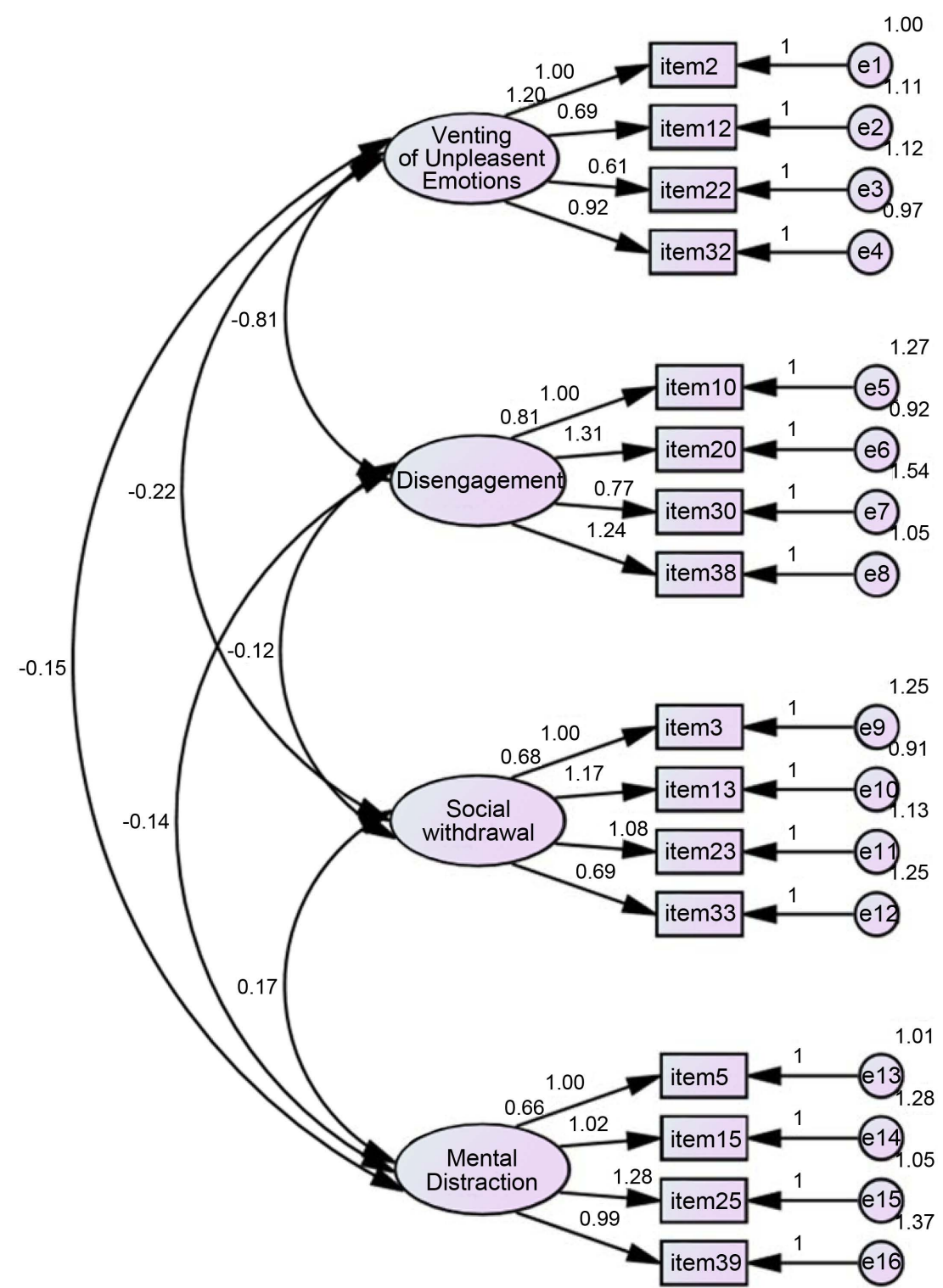

The ellipses represent unrealized buildings and squares represent measured variables. All parameters are normalized and are significant at $p<0.05$. The remaining differences are shown in small circles.

Figure 2. The hypothesized model of 6-factor (TOC) of the Arabic version of ISCCS.

For the exploratory factor analysis (Table 7), the factor loadings of the items for the 6-factor model were between 0.547 and 0.757 and between 0.535 and 0.795 for the four-factor model (see Table 8).

Finally a multivariate analysis, MANOVA was conducted to examine the effects of gender and the kind of sport practiced. The results revealed an important effect of sex [Wilks' lambda $=88 ; \mathrm{F}=5.54 ; \mathrm{df}=408 ; p<0.001$ ] and the kind of sports practiced [Wilks' lambda $=77 ; \mathrm{F}=12.73 ; \mathrm{df}=408 ; p<0.001$ ] on the use of coping strategies.

\section{Discussion}

For stability over time, we find that the test-retest reliability scores are generally greater 
Table 7. Standardized solutions for factor loadings for the task oriented coping (TOC).

\begin{tabular}{|c|c|c|c|c|c|c|}
\hline \multirow{2}{*}{ Items } & \multicolumn{6}{|c|}{ Factor loadings } \\
\hline & 1 & 2 & 3 & 4 & 5 & 6 \\
\hline Item 1 & 0.693 & & & & & \\
\hline Item 11 & 0.670 & & & & & \\
\hline Item 21 & 0.663 & & & & & \\
\hline Item 31 & 0.651 & & & & & \\
\hline Item 19 & & 0.757 & & & & \\
\hline Item 37 & & 0.749 & & & & \\
\hline Item 29 & & 0.617 & & & & \\
\hline Item 9 & & 0.547 & & & & \\
\hline Item 7 & & & 0.730 & & & \\
\hline Item 17 & & & 0.728 & & & \\
\hline Item 35 & & & 0.716 & & & \\
\hline Item 27 & & & 0.612 & & & \\
\hline Item 16 & & & & 0.740 & & \\
\hline Item 6 & & & & 0.611 & & \\
\hline Item 34 & & & & 0.609 & & \\
\hline Item 26 & & & & 0.608 & & 0.351 \\
\hline Item 36 & & & & & 0.749 & \\
\hline Item 28 & & & & & 0.729 & \\
\hline Item 18 & & & & & 0.612 & \\
\hline Item 8 & & & & & 0.576 & \\
\hline Item 4 & & & & & & 0.713 \\
\hline Item 24 & & & & & & 0.713 \\
\hline Item 14 & & & & & & 0.646 \\
\hline
\end{tabular}

or equal than 0.9 , indicating a very good repeatability. Usually a high correlation means that the questionnaire remains rather stable over time and that an overall score very close in consecutive reversals. The score ranges between 0.70 and 0.80 for mental imagery and isolation and correlation is rather weak only for mental distraction strategy $(\mathrm{r}<$ 0.70).

The coefficients of reliability for mental imagery, control of thoughts, deployment efforts, seeking support, relaxation and isolation are high $(0.60<\alpha<0.70$; Kline, 1998). Also the Cronbach alpha coefficients are reasonable, as they range between 0.70 and 0.80 for logical analysis, the breakdown of unpleasant emotions, mental disengagement and distraction.

There are no big differences between the Arabic and the original form version based on internal consistency. Generally according to DeVellis (1991), alpha values that are 
Table 8. Standardized solutions for factor loadings for the emotion oriented coping (EOC).

\begin{tabular}{|c|c|c|c|}
\hline \multirow{2}{*}{ Items } & \multicolumn{3}{|c|}{ Factor loadings } \\
\hline & 1 & 2 & 3 \\
\hline Item 20 & 0.775 & & \\
\hline Item 32 & 0.746 & & \\
\hline Item 38 & 0.740 & & \\
\hline Item 2 & 0.735 & & \\
\hline Item 10 & 0.640 & & \\
\hline Item 12 & 0.626 & & \\
\hline Item 30 & 0.545 & & \\
\hline Item 22 & 0.535 & & \\
\hline Item 25 & & 0.778 & \\
\hline Item 5 & & 0.729 & \\
\hline Item 15 & & 0.707 & \\
\hline Item 39 & & 0.697 & \\
\hline Item 13 & & & 0.795 \\
\hline Item 23 & & & 0.737 \\
\hline Item 3 & & & 0.656 \\
\hline Item 33 & & & 0.646 \\
\hline
\end{tabular}

above 0.60 are considered as acceptable. Cronbach alpha coefficients of the Arabic version are very close to their original version counterparts.

The inter-scale correlations are significant as the average correlations vary between 0.20 and 0.40 (Briggs \& Cheek, 1986). According to Klein (2005), if the correlation between two factors equal to 1.00 (more than 0.85 ), the two factors are equal, which implies the omission of one of these two factors. In our study, the inter-scale correlations were in the acceptable range.

For the confirmatory factor analysis, chi-square as well as normed $\mathrm{X}^{2}\left(\mathrm{X}^{2} / \mathrm{df}\right)$ statistics values were important for both models. They are in an acceptable range $\left(\mathrm{X}^{2} \leq 1 / \mathrm{df} \geq\right.$ 3); see Wheaton, Muthen, Alwin and Summers (1977) and Tabachnick and Fidell, (2007).

The adjustment indices of the two models (the six factors model and the four factors model): CFI, TLI and GFI are lower than 0.90 (Roussel, Durrieu, Campoy, \& El Akre$\mathrm{mi}, 2002$ ). The RMSEA is respectively lower than 0.05 (Brown, 2006) and 0.06 (Hu \& Bentler, 1999), for the model with six factors and four factors.

For the exploratory factor analysis, standardized factor loadings can be interpreted as Pearson correlations estimated between an indicator and factor (Kline, 2005). Factor loads of 0.30 and above are commonly used (Brown, 2006).

For the model of coping oriented emotion, we distinguished saturations with 3 factors. Consequently, we estimated two models: the four factors and the three factors 
models $\left[\mathrm{X}^{2}=268.46 ; p<0.001 ; \mathrm{df}: 101 ; \mathrm{X}^{2} / \mathrm{df}=2,66 ; \mathrm{CFI}=0.89 ; \mathrm{TLI}=0.88\right.$; and RMSEA $=0.063]$. The results, suggest the best match of the original four-factor model that we used in the empirical study.

Finally united various analyses have concluded that mental imagery, control of thoughts, research support, the breakdown of unpleasant emotions, and disengagement vary with the athletes sex. More precisely, we find that most men use mental imagery and seeking support, whereas women use control thoughts, the breakdown of unpleasant emotions, and disengagement.

For the practiced sport, the coping strategies: research support, relaxation, ventilation unpleasant emotions, disengagement and mental distraction vary according to the kind of sport practiced. Formally athletes belonging to individual sports use more of the coping strategies indicated above.

However, our study suffers from some limitations. The first limitation concerns the timing of the administered questionnaire: The ISCCS was administered two hours at maximum one day after the competition (retrospective method). We know that this could be a source of bias, the output of the competition (success or failure) could have influenced the answers.

Also, the factor of stability ISCCS through the different phases of a sporting competition has not been tested (Gaudreau \& Blondin, 2002).

Further, we did not ISCCS cross-validation with other scales that invest coping, which affect the choice of the coping strategies used by our participants.

\section{Conclusion}

In this research, we propose an Arabic version of the inventory of coping strategies in sports competition. The loyalty of the ISCCS being excellent, the majority of the variables used for the validity and sensitivity to change are acceptable. The results of this study suggest that ISCCS is an evaluation tool in the sports field. Moreover, it is valid for assessing coping task-oriented and the coping emotion-oriented in the collective as well as in the individual sport before, during and after the competition. Psychologists and sports practitioners in the Arab world could use ISCCS to differentiate the coping strategies used by athletes and for preventive interventions.

\section{References}

Amirkhan, J. H. (1990). A Factor Analytically Derived Measure of Coping: The Coping Strategy Indicator. Journal of Personality and Social Psychology, from 1066 to 1074. http://dx.doi.org/10.1037/0022-3514.59.5.1066

André, N., \& Laurencelle, L. (2010). psychological Questionnaires for Physical Activity, Sport and Exercise, an Annotated Directory. Quebec: Presses of the University of Quebec.

Anshel, H., \& Kaissidis, A. N. (1997). Coping Style and Situational Appraisals as Predictors of Coping Strategies Following Stressful Events in Sports as a Function of Gender and Skill Level. British Journal of Psychology, 88, 263-276. http://dx.doi.org/10.1111/j.2044-8295.1997.tb02634.x

Anshel, Mr. H., Williams, L. R., \& Williams, S. M. (2000). Coping Style Following Acute Stress in 
Competitive Sport. The Journal of Social Psychology, 140, 751-773.

http://dx.doi.org/10.1080/00224540009600515

Arsan, N., \& Koruç, Z. (2011). Coping Strategies in Sports Competition inventory (ISCCS): Evaluating the Turkish Version by Confirmatory Factor Analysis. Journal of New World Sciences Academy, 6, Article ID: 2B0073.

Beal, D. J., Weiss, H. M., Barros, E., \& MacDermid, S. M. (2005). An Episodic Process Model of Affective Influences on Performance. Journal of Applied Psychology, 90, 1054. http://dx.doi.org/10.1037/0021-9010.90.6.1054

Bentler, P. M. (1990). Comparative Fit Indexes in Structural Models. Psychological Bulletin, 107, 238-246. http://dx.doi.org/10.1037/0033-2909.107.2.238

Briggs, S. R., \& Cheeks, J. M (1986). The Role of Factor Analysis in the Development and Evaluation of Personality Scales. Journal of Personality, 54, 106-148.

Brown, T. A. (2006). Confirmatory Factor Analysis for Applied Research. New York: Guilford.

Browne, V., \& Cudeck, R. (1993). Alternative Ways of Assessing Model Fit. In K. A. Bollen., \& J. S. Long (Eds.), Testing Structural Equation Models (pp. 136-162). Newbury Park, CA: Sage.

Bruchon, S. (2002). Health Psychology: Models, Concepts and Methods. Paris: Dunod.

Calmeiro, L., Tenenbaum, G., \& Eccles, D. (2010). Event Sequence Analysis of Appraisals and Coping during Trapshooting Performance. Journal of Applied Sport Psychology, 22, 392-407. http://dx.doi.org/10.1080/10413200.2010.495325

Calmeiro, L., Tenenbaum, G., \& Eccles, D. (2014). Managing Pressure: Patterns of Appraisals and Coping Strategies of Non-Elite and Elite Athletes during Competition. Journal of Sports Sciences, 32, 1813-1820. http://dx.doi.org/10.1080/02640414.2014.922692

Calmeiro, L., \& Tenenbaum, G. (2007). Fluctuation Cognitive-Emotional States during Performance of: An Idiographic Account. Revista de Psicología del Deporte, 16, 85-100.

Campillo, L. M. et al., (2013) Analysis of Coping Strategies in Players of Cadet Category, EFDeportes.com, Digital Magazine. Buenos Aires-Year 18-No. 181.

Carver, C. S., Scheier M. F., \& Weintraub, J. K. (1989). Assessing Coping Strategies: A Theoretically Based Approach. Journal of Personality and Social Psychology, 56, 267-283.

http://dx.doi.org/10.1037/0022-3514.56.2.267

Chabrol \& Callahan (2004). Defense Mechanisms and Coping. Paris: Dunod.

Costa, P. T., Somerfield, R., \& Mc Rae, R. R. (1996). Personality and Coping: A Reconceptualization. In N. Zeidner, \& S. Endler (Eds.), Handbook of Coping: Theory Research, Applications (pp. 44-61.). New York: Wiley.

Crocker, J., \& Major, B. C. (1998). Social Stigma Steele. In S. Fiske, D. Gilbert, \& G. Lindzey (Eds.), Handbook of Social Psychology (Vol. 2, pp. 504-553). Boston, MA: McGraw-Hill.

DeVellis, R. F. (1991) Scale Development: Theory and Application. London: Sage.

Doron, J., Stephan, Y., \& Le Scanff, C. (2013). Coping Strategies: A Review of Literature in Sport and Academic Contexts. European Review of Applied Psychology, 63, 251-334.

Doron, J., \& Gaudreau, P. (2014). A Point by Point Analysis of Performance in a Fencing Match: Psychological Processes Associated with Winning and Losing Streaks. Journal of Sport and Exercise Psychology, 36, 3-13. http://dx.doi.org/10.1123/jsep.2013-0043

Endler, N. S., \& Parker, J. D. A. (1990). Coping Inventory for Stressful Situations. Toronto: Multihealth Systems.

Evans, B., Hoar, S. D., Gebotys, R. J., \& Marchesin, C. A. (2014). Endurance Athletes' Coping Function Uses Competitive Suffering during Episodes. European Journal of Sport Science, 14, 368-375. http://dx.doi.org/10.1080/17461391.2013.832803 
Folkman, S., \& Moskowitz, J. T. (2000). Positive Affect and the Other Side of Coping. American Psychologist, 55, 647-654. http://dx.doi.org/10.1037/0003-066X.55.6.647

Gaudreau, P., \& Blondin, J. P. (2002). Development of a Questionnaire for the Assessment of Coping Strategies Employed by Athletes in Competitive Sports Settings. Psychology of Sport and Exercise, 3, 1-34. http://dx.doi.org/10.1016/S1469-0292(01)00017-6

Gaudreau, P., Nicholls, A., \& Levy, A. R. (2010). The Ups and Downs of Coping and Sport Achievement: An Episodic Process of Analysis within Person Associations. Journal of Sport \& Exercise Psychology, 32, 298-311. http://dx.doi.org/10.1123/jsep.32.3.298

Hoar, S. D., Kowalski, K. C., Gaudreau, P., \& Crocker, P. R. E. (2006). A Review of Coping in Sport. In S. Hanton, \& S. D. Mellalieu (Eds.), Literature Reviews in Sport Psychology (pp. 4790). New York: Nova Science Publishers.

Hoyle, R. H., \& Panther, A. T. (1995). Writing about Structural Equation Models. In R. H. Hoyle (Ed.), Structural Equation Modeling: Concepts, Issues, and Applications (pp. 158-175.). London: Sage.

Hu, L. T., \& Bentler, M. W. (1999). Cutoff Criteria for Fit Indexes in Covariance Structure Analysis: Conventional Versus New Alternatives Criteria. Structural Equation Modeling, 6, 1-55. http://dx.doi.org/10.1080/10705519909540118

Jöreskog, K. G., \& Sörbom, D. (1984). Lisrel VI. Analysis of Linear Structural Relationships by Maximum Likelihood, Instrumental Variables, and Least Squares Methods. Mooresville: Scientific Software.

Kline, R. (2005). Principles and Practice of Structural Equation Modeling (2nd ed.). New York: Guilford.

Kowalski, K., \& Crocker, P. R. E. (2001). Development and Validation of the Questionnaire for Teens Coping Function in Sport. Journal of Sport and Exercise Psychology, 23, 136-155. http://dx.doi.org/10.1123/jsep.23.2.136

Lazarus, R. S., \& Folkman, S. (1984). Coping and Adaptation. In W. D. Gentry (Ed.), The Handbook of Behavioral Medicine (pp. 282-325.). New York: Guilford.

Molinero, O., Salguero, A., \& Márquez, S. (2010). Psychometric Properties and Three Dimensional Structure of the Spanish Adaptation of the Inventory Adjustment for the Sport Compétition. Psicothema, 975-982.

Moos, R. H. (1993). Coping Responses Inventory: CRI from Adults. Professional Manual, Odessa, TX: Psychological Assessment Resources.

Nicholls, A. R., \& Polman, R. C. J. (2007). Coping in Sport: A Systematic Review. Journal of Sports Sciences, 25, 11-31. http://dx.doi.org/10.1080/02640410600630654

Ponnelle, S., \& Lancry, A. (2002). Adjustment Strategies and Environmental and Personal Resources in Dynamic Stress. In M. Neboit, \& M. Vézina (Eds.), Stress at Work and Mental Health (pp. 59-77). Toulouse: Octares.

Roussel, P., Durrieu, F., Campoy, E., \& El Akremi, A. (2002). Methods of Structural Equations: Research and Application Management. Paris: Economica.

Shrout, P. E., \& Fleiss, J. L. (1979). Intraclass Correlations: Uses in Assessing Miss Reliability. Psychological Bulletin, 86, 420-428. http://dx.doi.org/10.1037/0033-2909.86.2.420

Skinner, E. A., Edge, K., Altman, J., \& Sherwood, H. (2003). Searching for the Structure of Coping: A Critical Review and Category Systems for Classifying Ways of Coping. Psychological Bulletin, 129, 216-269. http://dx.doi.org/10.1037/0033-2909.129.2.216

Smith, R. E., Schutz, R. W., Smoll, F., \& Ptacek, J. T. (1995). Development and Validation of a Multidimensional Measure of Sports-Specific Psychological Skills: The Athletic Coping Skills 
Inventory-28. Journal of Sport and Exercise Psychology, 17, 379-398.

http://dx.doi.org/10.1123/jsep.17.4.379

Stone, A. A., \& Neale, J. M. (1984). New Measure of Daily Coping: Development and Preliminary Results. Journal of Personality and Social Psychology, 61, 892-906.

http://dx.doi.org/10.1037/0022-3514.46.4.892

Tabachnick, B. G., \& Fidell, L. S. (2007). Using Multivariate Statistics (5th ed.). New York: Allyn and Bacon.

Tabachnick, B. G., \& Fidell, L. S. (1996). Using Multivariate Statistics (3rd ed.). New York: Harper Collins.

Vallerand, R. J. (1989). Towards Transcultural Validation Methodology of Psychological Questionnaires: Implications for French Research. Canadian Psychology, 30, 662-689. http://dx.doi.org/10.1037/h0079856

Wheaton, B., Muthen, B., Alwin, D. F., \& Summers, G. (1977). Assessing Reliability and Stability in Panel Models. Sociological Methodology, 8, 84-136. http://dx.doi.org/10.2307/270754 


\section{Appendix}

Supplementary material: Arabic translated version of the ISCCS.

\section{استيبان استراتيجيات التأقلم فى مواجهة قلق المنافهة}

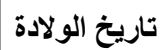
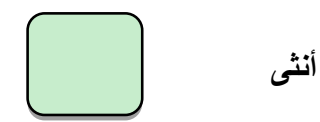

ذكر
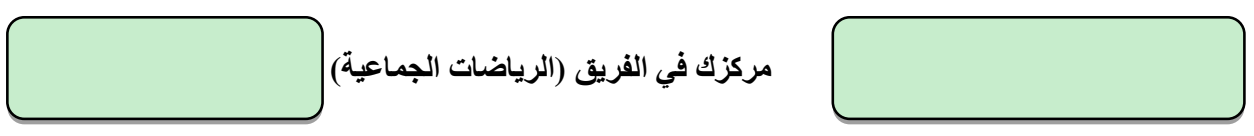

الاختصاص الرياضي

$$
\begin{aligned}
& \text { لا توجد إجابات صحيحة أو إجابات خاطئة }
\end{aligned}
$$

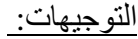

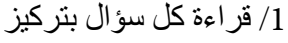

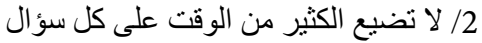

3/ اختر الجو اب الذي يصف بشكل أفضل ما شعرت به دقائق قبل المباراة

\begin{tabular}{|c|c|c|c|c|c|c|}
\hline دائما & غالبا & 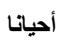 & نادرا & أبدا & 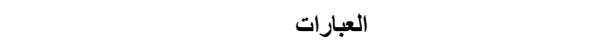 & \\
\hline 5 & 4 & 3 & 2 & 1 & تصورت أنني في منتهى السيطرة على الوضع قبل المسابقة & 01 \\
\hline 1 & 2 & 3 & 4 & 5 & نطقت بألفاظ سيئة في سري أو بصوت عالي لأعبر عن غضبي & 02 \\
\hline 5 & 4 & 3 & 2 & 1 & ابتعدت عن بقية زملائي & 03 \\
\hline 5 & 4 & 3 & 2 & 1 & انعزلت مع نفسي لتوفير جه مستمر في المسابقة & 04 \\
\hline 5 & 4 & 3 & 2 & 1 & شغلت نفسي بالتفكير في أشياء أخرى غير المسابقة & 05 \\
\hline 5 & 4 & 3 & 2 & 1 & حاولت ألا أقع تحت تأثير المنافس & 06 \\
\hline 5 & 4 & 3 & 2 & 1 & طلبت نصائح من حولي لتساعدني في تحضير نفسي ذهنيا & 07 \\
\hline 5 & 4 & 3 & 2 & 1 & حاولت أن أجعل جسمي في حالة استرخاء & 08 \\
\hline 5 & 4 & 3 & 2 & 1 & قمت بتحليل إنجازاتي في المسابقات السابقة & 09 \\
\hline 1 & 2 & 3 & 4 & 5 & فقدت كل الأمل في الوصول إلى هدفي في المسابقة & 10 \\
\hline 5 & 4 & 3 & 2 & 1 & قمت باستعادة تنفيذ أحسن حركاتي الفنية في ذهني & 11 \\
\hline 1 & 2 & 3 & 4 & 5 & كنت غاضبا & 12 \\
\hline 5 & 4 & 3 & 2 & 1 & انزويت (ابتعلت) وحدي في مكان ملائم للتفكير & 13 \\
\hline 5 & 4 & 3 & 2 & 1 & فكرت ببذل مجهود كبير في المسابقة & 14 \\
\hline 5 & 4 & 3 & 2 & 1 & فكرت في هوياتي المفضلة لأجتب التفكير في المسابقة & 15 \\
\hline 5 & 4 & 3 & 2 & 1 & حاولت إزاحة شكوكي في قدراتي وذلك بالتفكير في أثياء إيجابية & 16 \\
\hline 5 & 4 & 3 & 2 & 1 & طلبت نصائح تساعدني في المباراة من زملاني في الفريق & 17 \\
\hline 5 & 4 & 3 & 2 & 1 & حاولت التخفيف من حدة توتر عضلاتي & 18 \\
\hline 5 & 4 & 3 & 2 & 1 & قمت بتحليل نقاط ضعف المنافس & 19 \\
\hline 1 & 2 & 3 & 4 & 5 & أصبحت محبطا (أصبحت يائسا) & 20 \\
\hline 5 & 4 & 3 & 2 & 1 & تخيلت أنني بصدد تحقيق أداء عظيما في المسابقة & 21 \\
\hline
\end{tabular}




\section{Continued}

\begin{tabular}{|c|c|c|c|c|c|c|}
\hline 1 & 2 & 3 & 4 & 5 & عبرت عن استيائي (عبرت عن ضيقي) & 22 \\
\hline 5 & 4 & 3 & 2 & 1 & اختليت بنفسي (انفردت بنفسي) & 23 \\
\hline 5 & 4 & 3 & 2 & 1 & عزمت على تقليم أقصى جها في المسابقة & 24 \\
\hline 5 & 4 & 3 & 2 & 1 & قمت بأثياء مسلية حتى لا أفكر في المسابقة & 25 \\
\hline 5 & 4 & 3 & 2 & 1 & حاولت استبدال أفكاري السلبية بأخرى إيجابية & 26 \\
\hline 5 & 4 & 3 & 2 & 1 & وضعت ثقتي في شخص جدير بها & 27 \\
\hline 5 & 4 & 3 & 2 & 1 & قمت بتمارين للاسترخاء & 28 \\
\hline 5 & 4 & 3 & 2 & 1 & فكرت في الحلول الممكنة للسيطرة على الوضع & 29 \\
\hline 1 & 2 & 3 & 4 & 5 & تمنيت أن تتتهي المباراة فورا & 30 \\
\hline 5 & 4 & 3 & 2 & 1 & تصورت القيام بأفضل مباراة لي في حياتي & 31 \\
\hline 1 & 2 & 3 & 4 & 5 & عبرت عن مثاعر الإحباط (اليأس) & 32 \\
\hline 5 & 4 & 3 & 2 & 1 & بحثت عن الهدوء & 33 \\
\hline 5 & 4 & 3 & 2 & 1 & فكرت في نجاحي عوضا عن فثلي & 34 \\
\hline 5 & 4 & 3 & 2 & 1 & تحدثت إلى شخص قادر على تحفيزي & 35 \\
\hline 5 & 4 & 3 & 2 & 1 & جعلت عضلات جسمي في حالة استرخاء & 36 \\
\hline 5 & 4 & 3 & 2 & 1 & قت بتحليل متطلبات المباراة & 37 \\
\hline 1 & 2 & 3 & 4 & 5 & لم أعد أؤمن بقدراتي (يئست من قدرني) على تحقيق الفوز & 38 \\
\hline 5 & 4 & 3 & 2 & 1 & فكرت في عائلتي وأصدقائي لإبعاد تركيزي على المسابقة & 39 \\
\hline
\end{tabular}

الأسئلة المؤشر عليها باللون الأسود هي أسئلة ذات اتجاه عكسي

Submit or recommend next manuscript to SCIRP and we will provide best service for you:

Accepting pre-submission inquiries through Email, Facebook, LinkedIn, Twitter, etc.

A wide selection of journals (inclusive of 9 subjects, more than 200 journals)

Providing 24-hour high-quality service

User-friendly online submission system

Fair and swift peer-review system

Efficient typesetting and proofreading procedure

Display of the result of downloads and visits, as well as the number of cited articles

Maximum dissemination of your research work

Submit your manuscript at: http://papersubmission.scirp.org/

Or contact ape@scirp.org 